MARIUSZ KAIRSKI

Uniwersytet Gdański

\title{
Poznawać, wierzyć, kochać. O Wojciechu Bębnie i jego wielu światach
}

$\mathrm{T}$ rudno pisać o osobie bliskiej, z którą się przebywa i współpracuje na co dzień. I nie tylko o brak dystansu tu chodzi. Trudność ta wynika też - a może przede wszystkim - z tego, że bohater tekstu to postać naprawdę nietuzinkowa. I nie jest to przesada. Jego życiorysem można by obdzielić sporą grupę ludzi, a i osobowościowo jest to jednostka wielowymiarowa, pełna sprzeczności. Lecz tylko pozornych. Wielkość Wojciecha Bębna polega bowiem nie na tym, czego w życiu dokonał (a dokonał wiele, w wielu dziedzinach życia), lecz na tym, że owe sprzeczności ułożył w swym sercu tak, że zagrały piękny koncert zwany życiem. No bo jak tu pisać o kimś, kto jest księdzem i profesorem akademickim z dwoma doktoratami, habilitacją i belwederską profesurą. Nauczycielem akademickim i katechetą. Znawcą dobrych potraw i trunków, kolekcjonerem sztuki tubylczej, człowiekiem otaczającym się drogimi gadżetami i zarazem osobą, która rozdaje swe pieniądze potrzebującym. Prowadzi wysublimowane dysputy teologiczne o sensie działalności misyjnej i opowiada rubaszne, niepoprawne politycznie dowcipy. Znaleźć w tym harmonię, to dopiero życiowe osiągnięcie!

Nasz bohater urodził się 28 lutego 1949 roku w Działoszynie. Maturę zdał w liceum w Łodzi, a następnie studiował w Misyjnym Seminarium Duchownym Księży Werbistów w Pieniężnie. W roku 1975, po ukończeniu seminarium oraz studiów teologicznych, udaje się do Irlandii, gdzie rozpoczyna naukę języka angielskiego. Rok później otrzymuje skierowanie do pracy w Australii i Oceanii, gdzie przez prawie trzy dekady prowadzi działalność duszpasterską oraz badania ludów Mórz Południowych. 


\section{Pierwsze doświadczenia}

Początkowo trafia na wulkaniczną wyspę Manam, leżącą na Morzu Bismarcka, u północnych wybrzeży Papui-Nowej Gwinei. Pierwsze doświadczenia misjonarza i terenowego antropologa to nie tylko fascynacja nowością i trudy pierwszych doświadczeń. Szybko, dla bystrego obserwatora, jakim jest, rzeczywistość staje się realnością nieoczywistą. Pierwsze pytania o to, jak badać i jak ewangelizować, mnożą się i komplikują. Kiedy po dość krótkim pobycie opuszczał wyspę, był przekonany, że już tam nie wróci. Wszak czekały go nowe wyzwania i nowe miejsca. Na Manam wprawdzie nie wrócił, ale tamtejszych tubylców spotkał po latach. Wyspa była dość niebezpieczna z uwagi na częste erupcje wulkanu. Płynące rzeki lawy, popiołów i pyłu wulkanicznego pochłonęły wiele ofiar. Rząd Papui-Nowej Gwinei zdecydował się ewakuować wszystkich mieszkańców. Wojciech Bęben odwiedza przesiedlonych na wybrzeże głównej wyspy. Ich trudności adaptacyjne, niechęć do życia na nieswojej ziemi, tęsknota, chaotyczność i przymusowość przesiedlenia wywołały refleksję: czy było to konieczne? Czy nie działano pośpiesznie i rutynowo? Nasz badacz wie z wcześniejszych obserwacji, że tubylcy dysponują ogromną wiedzą o wulkanie i jego aktywności. Wszak wulkan wybucha co pewien czas, okoliczni mieszkańcy mierzą się więc z tym doświadczeniem od setek, jeśli nie tysięcy lat. Potrafią przewidzieć siłę wybuchu, kierunek spływania lawy. Antropolog słucha ich żalów na państwową administrację i lamentów nad opuszczoną ojczyzną. Uświadomienie sobie, że tubylcy mają bogatą praktyczną wiedzę o własnym świecie, pozwalającą wygodnie żyć w ich środowisku naturalnym, jest ważnym składnikiem jego doświadczenia. Stara się uwrażliwić na nie agentów administracji państwowej, kościelnej i organizacji pomocowych. „Najpierw ich zapytajcie, czego chcą, a dopiero potem zastanawiajcie się, jak im pomóc. Trzeba słuchać ludzi, pytać ich, oni żyją na swojej ziemi od tysięcy lat, mają wiedzę, umieją dawać sobie radę w trudnych sytuacjach. Gdy chce się pomóc, dobra wola nie wystarczy, trzeba słuchać tych, którym chcemy nieść pomoc". Powtarza te słowa jak mantrę, zawsze i wszędzie.

\section{Doświadczenia formujące}

Pierwszy sześcioletni pobyt ma miejsce na wyspie Bam (Biem). To niewielka wyspa w archipelagu Schoutena (Eastern Schouten Islands albo Le Maire Islands), w stosunkowo niewielkiej odległości od wyspy Manam (60 km). Ludy zamieszkujące obie wyspy są do siebie podobne kulturowo i językowo, otaczają je podobne warunki naturalne, mają podobne problemy życiowe. Także na tej wyspie dominuje widok pięknego w swej grozie wulkanu. Wojciech Bęben jest pierwszy. Nikt przed nim nie badał tej wyspy. Może posiłkować się wiedzą o mieszkańcach odległej o niecałe 100 km wyspy Wogeo. Praca I. Hogbina (The Island of Menstruating Men. Religion in Wogeo, New Guinea. 1970, London: Chandler Publishing Company.) jest inspirująca, lecz odmienność Bam zmusza do wysiłku. 
Badacz pełną parą rzuca się w wir pracy. Uczy się języka bam, żyje życiem tubylców na terenie głównej osady wyspy. Rozmawia, radzi, słucha, poznaje. Sercem i umysłem jest z mieszkańcami wyspy. Zafascynowany poznaje złożoność ich kultury, odkrywa zależności między różnymi sferami ich życia. Szuka klucza, by je zrozumieć. Jednym z ważnych obszarów poznania staje się prawo tubylcze, zwyczajowe i jego kolizja z prawem stanowionym, państwowym. Możliwości koegzystencji tych systemów, praktyczne sposoby współistnienia - oto wyzwanie intelektualne i pastoralne antropologa-misjonarza. Jest to zarazem droga do równowagi pomiędzy obydwoma powołaniami. Zaowocuje mądrością i refleksją niespotykaną wśród misjonarzy. Szacunek dla wartości innych ludzi, nienarzucanie i nieopresywność. Słuchać, słuchać, słuchać. Z tego doświadczenia rodzi się Mały świat wokót wulkanu. Tradycyjne normy zwyczajowe w życiu wyspiarzy Biem w Papui Nowej Gwinei (2004, Warszawa: Wydawnictwo DiG). To nie tylko rys kultury mieszkańców Bam. To także, a może przede wszystkim, zarys procesów funkcjonowania tego ludu w relacji ze światem zewnętrznym. Z systemem prawnym nowogwinejskiego państwa, z innymi systemami wartości propagowanymi przez misjonarzy różnych wyznań, ze szkołą, z organizacjami pozarządowymi. Na wszystkich poziomach egzystencji dochodzi do kolizji, negocjacji i reinterpretacji starych i nowych porządków. Mieszkańcy Bam nie są biernymi i niedoskonałymi imitatorami współczesnego świata. Twórczo i starannie przekształcają nową rzeczywistość na swój sposób, adaptują ją do swoich potrzeb. To nowe, ważne doświadczenie dla naszego badacza. Widzi on nieuchronność zmian w życiu tubylców, ale widzi też ich sprawczość nadającą zmianom kształt i kierunek. Tubylec to nie tylko przedmiot opresji kolonialnej i postkolonialnej, jak często chcemy widzieć procesy w tzw. Trzecim Świecie. To ktoś, kto zamieszkuje centrum swego świata, a nie peryferie świata globalnego. Badacz poznaje system wartości mieszkańców Bam, dokonuje jego opisu i wyjaśnienia go tak, jak go zrozumiał. Uczy się wnikliwości i cierpliwości. Na to trzeba czasu, motywacji i otwarcia na Innych. Trzeba też pracowitości i sprytu. Poznanie i rozumienie Innych nie jest łatwe. Monografia o Bam to cenny owoc tego wysiłku. Plon pracowitości i pokory.

\section{Doświadczenia wzrostu}

W przerwach między dłuższymi pobytami Wojciech Bęben odwiedza inne zakątki Nowej Gwinei. Na krótko trafia do Pumakos w krainie ludu Enga, w górach środkowej części kraju. Lecz jego ulubionym miejscem pobytu jest dorzecze rzeki Sepik. Wędruje i zatrzymuje się na dłużej wśród ludów Angoram, Iatmul, Chambiri i Arapesh. Ludy tego regionu fascynują go, bo to prawdziwi artyści. Świątynie, maski, rzeźby, kolory i finezyjne wzory, realistyczne i abstrakcyjne. Niezwykłe bogactwo obrzędów, wierzeń i mitów. Nasz bohater jest w swoim żywiole. Dokumentuje sztukę Sepiku, rysuje, szkicuje, maluje i fotografuje. Zbiera też eksponaty kultury materialnej. Jego dusza artysty i zmysł estetyczny dostrzegają prawdziwe dzieła sztuki. Potrafi odróżnić je od obiektów 
wykonanych szybko, schematycznie i niestarannie - dla przybywających tam dość często turystów i handlarzy. Jako badacz nie jest tu pierwszy. Poprzedzili go współtwórcy nowoczesnej antropologii: George Bateson, Margaret Mead, Reo Fortune. Zna ich dorobek, twórczo rozwija niektóre wątki badań, rejestruje dynamikę zmian i ich kierunek. Interesują go powiązania życia gospodarczego z wierzeniami i rytuałami. Śledzi wątki i szuka analogii. Wszystko wymaga dbałości, staranności. Wymaga też wysiłku. Ludzie i rośliny stanowią jedność, jedno społeczeństwo. Połączone szacunkiem i dbałością o siebie. Rośliny wzrastają jak ludzie (a może na odwrót). Nasz badacz podejmuje tematy do tej pory słabo udokumentowane i rzadko analizowane, jak na przykład wymiar artystyczny i estetyczny architektury tego regionu, w szczególności świątyń (tambaran) i ich wyposażenia. Uczeń z duszą artysty i estety spotkał godnych siebie Mistrzów. W przerwach między badaniami rezyduje w Wewak i odwiedza w odległej peryferyjnej dzielnicy mieszkających tam młodych Arapeshów, którzy kształcą się w stolicy regionu. Poznaje ich radości i obawy. Życie daleko od domu, w zupełnie innym kulturowo i etniczne świecie, nie jest łatwe. Pyta o motywy i determinację. Dostrzega w nich zaczątki nowego społeczeństwa miejskiego. Doświadczenia znad Sepiku dopełniają procesu ukonstytuowania się badacza i misjonarza pełnej krwi. Pozwalają mu stworzyć własną filozofię życia tam, gdzie zrozumienie innych opiera się na życzliwej wśród nich obecności. Nasz badacz jest raczej słuchaczem niż głosicielem. Wsłuchuje się w rytm i brzmienie odmiennych kultur. Jest obecny wśród ludzi, ale nie jest ekspansywny ani narzucający się. Nic na siłę. Radzi, gdy jest pytany, nie poucza nieproszony. Jest Mistrzem i Uczniem zarazem. Dlatego jest tam lubiany i obdarzany szacunkiem. Nie jest figurą eksploratora-kolonisty-misjonarza. W kraju, w którym nowe tubylcze elity rządzące krajem przejęły wzorce swych dawnych ciemiężycieli i traktują mieszkańców wnętrza wyspy tak, jak kiedyśs same były traktowane, taka postawa nie jest zwykła, powszechna. A przy tym jest też niepokojąca, w najlepszym razie wzbudza uśmiech na ustach najróżniejszych decydentów administracji państwowej i kościelnej.

\section{Doświadczenia pełni}

Jeszcze jedna kraina jest ważna w życiu Wojciecha Bębna: Wyspy Cieśniny Torresa, a konkretnie Wyspa Czwartkowa. Styk kontynentu australijskiego z Pacyfikiem. Ludy austronezyjskie i australijskie. Podobne formy adaptacji do środowiska morskiego. Piękna kraina, choć do niedawna dość niebezpieczna. Jeszcze na początku XX wieku ludy z południowo-wschodniej części Papui Holenderskiej dokonywały zbrojnych napadów na mieszkańców wysp Cieśniny. Porywano kobiety i dzieci, zabijano mężczyzn. Brytyjskie władze stanu Queensland wysyłają zbrojne wyprawy odwetowe. Dochodzi do kryzysu dyplomatycznego między Holandią a Wielką Brytanią. Pamięć tych napadów do dziś jest żywa. Ale współczesność wysp też jest ciekawa. Co w nich pociąga badacza? Przenikanie się kultury ludów Australii i Oceanii - od niepamiętnych czasów. W czasach historycznych, 
w XIX wieku - przenikanie się kultur tubylczych i kultur imigrantów azjatyckich. I wreszcie w XX wieku - przenikanie się tego, co lokalne z tym, co globalne. Etnologiczne "tu i teraz" to ciągła zagadka. Co z tego wyjdzie? - Z różnych wzorców, różnych ras, różnych interesów? Polityka organizacji państwowych, organizacji tubylczych, związków wyznaniowych, grup pomocowych. Złożone procesy, złożone zależności. Rajskie wyspy, próbujące w potoku spraw codziennych sprostać wymaganiom jutra. Wszystko się zmienia, jest bardzo złożone i nieoczywiste. Odczucia sprzed lat wzmacniają się. Ale nie wywołują niepokoju. Raczej zadumę, zrozumienie i akceptację. Taki ten świat już jest, tak to się plecie.

Potrzeba spojrzenia z zewnątrz, oderwania się od "tu i teraz", wymusza inne podróże i inne spotkania. Doświadczenia napędzają się wzajemnie, pozwalają na nowe oglądy i syntezy. Wojciech Bęben podróżuje po Australii, Nowej Zelandii, trafia na Samoa. Wtedy to rodzi się synteza, myśl o drogach adaptacji ludów tubylczych w świecie współczesnym. Tam, gdzie tubylcy Nowej Zelandii (Maorysi) znajdują swe miejsce w nowoczesnym kraju, tam mieszkańcy Nowej Gwinei szukają formuły na naród w państwie pełnym zjawisk postkolonialnych. A z kolei tubylcy australijscy muszą sobie odpowiedzieć na pytanie, czy chcą istnieć. Jako zbiorowości i jako jednostki. To refleksja - osobista, poparta wieloletnim doświadczeniem, bolesna, prorocza.

Trzeba jeszcze wspomnieć o innych wyzwaniach pracowitego życia. Niestrudzony podróżnik przez 4 lata kieruje The Melanesian Institute for Pastoral and Socio-Economic Service w Goroka (stolicy Eastern Highlands Province, Papua-Nowa Gwinea), gdzie wykłada antropologię. W późniejszym czasie wykłada też na Yarra Theological Union w Melbourne, w Australii.

Wreszcie następuje nasycenie. Czas na podsumowanie i podzielenie się doświadczeniem. Utrwalić i udokumentować myśl. To znowu czas pracowity. Wojciech Bęben wraca do kraju pod koniec lat 90., podejmuje pracę w Katedrze Etnologii i Antropologii Kulturowej Uniwersytetu Wrocławskiego. Następnie przenosi się do Warszawy, gdzie do 2008 roku pracuje w Instytucie Etnologii i Antropologii Kulturowej UW. Na stanowisku profesora zatrudniony jest też na Uniwersytecie Stefana Wyszyńskiego w Warszawie oraz w Wyższej Szkole Zarządzania w Gdańsku. Wreszcie w roku 2008 podjął się wyzwania utworzenia całkowicie nowego ośrodka etnologicznego na Uniwersytecie Gdańskim, którym z sukcesami kierował aż do roku 2019 (zob. Jacek Splisgart, w tym tomie).

Systematycznie i wytrwale zdobywał kolejne stopnie naukowe. Przygotował dwie prace magisterskie, pierwszą obronił w roku 1980 na Katolickim Uniwersytecie Lubelskim (promotor Henryk Zimoń), drugą na Uniwersytecie Kardynała Stefana Wyszyńskiego w Warszawie, w roku 1985 (promotor Władysław Kowalak). Pracował, jakby chciał nadrobić czas. Otworzył dwa przewody doktorskie, które obronił w 1987 roku. Jeden z nauk humanistycznych w zakresie etnologii w Katedrze Etnologii i Antropologii Kulturowej Uniwersytetu Warszawskiego. Temat pracy: Obrzędy przejścia u Arapeszów w Papui Nowej Gwinei, promotor: prof. dr hab. Zofia Sokolewicz. Drugi, z teologii w zakresie religioznawstwa, w Zakładzie Misjologii Akademii Teologii Katolickiej w Warszawie. Temat pracy: Religijne 
aspekty tradycyjnych wierzeń i obrzędów religijnych ludu Arapesz w Papui Nowej Gwinei, promotor: prof. UWr dr hab. Franciszek Rosiński.

Głównymi obszarami zainteresowań Wojciecha Bębna w tym czasie były tradycyjne wierzenia ludów Australii i Oceanii, zależność pomiędzy ich językami tubylczymi a systemami myślenia, moralność i etyka ludów Australii i Oceanii, ich prawo zwyczajowe, działalność misyjna w wymiarze teologicznym, misjonologicznym i antropologicznym. W 2005 roku uzyskał tytuł doktora habilitowanego w zakresie etnologii, w Instytucie Archeologii i Etnologii Polskiej Akademii Nauk w Warszawie, na podstawie rozprawy Mały świat wokót wulkanu. Tradycyjne normy zwyczajowe w życiu wyspiarzy Biem na Papui Nowej Gwinei, a tytuł profesora nauk humanistycznych - w lipcu 2015 roku.

Otrzymał też szereg prestiżowych nagród: w roku 2005 - Nagrodę CLIO Rady Wydziału Historycznego Uniwersytetu Warszawskiego za książkę Mały Świat wokót wulkanu. Tradycyjne normy zwyczajowe w życiu wyspiarzy Biem w Papui Nowej Gwinei (2004, Warszawa: Wydawnictwo DiG), w tym samym roku został nominowany do Nagrody Ministerstwa Nauki i Informatyzacji w konkursie „Popularyzator Nauki”, w roku 2013 otrzymał Nagrodę Rektora UG za pracę Aborygeni, pierwsi nomadzi. Życie i kultura (2013, Gdańsk: Wydawnictwo UG), a w roku 2020 - Nagrodę im. Benedykta Polaka przyznawaną przez Kapitułę Nagrody im. Benedykta Polaka za szczególne zasługi w poznawaniu odległych kultur świata i ich popularyzację w Polsce.

Przeszedłszy na zasłużoną emeryturę po pracowitym okresie badań, studiów i nauczania, pisze i pisze. Przed nim jeszcze książka o estetyce i architekturze na Bam. Wspomnienia i przemyślenia. Starczy czasu, jeśli chcemy go sobie dać. Wszystkiego dobrego, Profesorze.

\section{Prace prof. dr hab. Wojciecha Bębna}

\section{KSIĄŻKI}

Bęben, W. (2004). Mały świat wokót wulkanu: tradycyjne normy zwyczajowe w życiu wyspiarzy Biem w Papui Nowej Gwinei. Warszawa: Instytut Etnologii i Antropologii Kulturowej UW/Wydawnictwo DiG.

Bęben, W. (2006). Dzieci kazuara. Lublin: Wydawnictwo GAUDIUM.

Bęben, W. (2012). Aborygeni, pierwsi nomadzi. Życie i kultura. Gdańsk: Wydawnictwo Uniwersytetu Gdańskiego.

Bęben, W. (2015). Tańczacy kanibale. Wyspiarze Cieśniny Torresa. Gdańsk: Wydawnictwo Uniwersytetu Gdańskiego.

Bęben, W. (2016). Yamy, trucizna i duchy. Arapesze z Papui-Nowej Gwinei. Gdańsk: Wydawnictwo Uniwersytetu Gdańskiego.

Bęben, W. (2019). Dzieciństwo na Antypodach. Gdańsk: Wydawnictwo Uniwersytetu Gdańskiego. 


\section{ROZDZIAEY W KSIĄŻKACH}

Bęben, W. (1996). Istoty nadprzyrodzone i ich kult u Arapeszów. W: E. Pietraszek, B. Kopydłowska-Kaczorowska (red), Ludy i kultury Australii i Oceanii: materiały z Vkonferencji naukowej zorganizowanej we Wrocławiu w dniach 26-27 listopada 1988 r. przez Katedrę Etnografii Uniwersytetu Wrocławskiego (s. 49-59). Wrocław: Katedra Etnologii Uniwersytetu Wrocławskiego.

Bęben, W. (1996). Ryty przejścia u Arapeszów. W: E. Pietraszek, B. Kopydłowska-Kaczorowska (red.), Ludy i kultury Australii i Oceanii: materiały z V konferencji naukowej zorganizowanej we Wroctawiu w dniach 26-27 listopada 1988 r. przez Katedre Etnografii Uniwersytetu Wrocławskiego (s. 61-70). Wrocław: Katedra Etnologii Uniwersytetu Wrocławskiego.

Bęben, W. (1997). Społeczność arabeska. W: A. Kuczyński (wyb., red.), Polskie opisanie świata: studia z dziejów poznania kultur ludowych i plemiennych, t. 2 Ameryka i Australia z Oceania (s. 381-394). Wrocław: Wydawnictwo Uniwersytetu Wrocławskiego.

Bęben, W. (1998). Bigmeni na wyspie Biem w Papui-Nowej Gwinei. W: B. Kopydłowska-Kaczorowska, F.M. Rosiński (red.), Ludy i kultury Australii i Oceanii: materiaty z VI konferencji naukowej zorganizowanej we Wroctawiu w dniach 26 i 27 listopada 1994 r. przez Katedrę Etnologii Uniwersytetu Wrocławskiego (s. 107-112). Wrocław: Katedra Etnologii Uniwersytetu Wrocławskiego.

Bęben, W. (1998). Mead - królowa wyspy Biem, Papua-Nowa Gwinea. W: B. Kopydłowska-Kaczorowska, F.M. Rosiński (red.), Ludy i kultury Australii i Oceanii: materiaty z VI konferencji naukowej zorganizowanej we Wroctawiu w dniach 26 i 27 listopada 1994 r. przez Katedrę Etnologii Uniwersytetu Wrocławskiego (s. 129-139). Wrocław: Katedra Etnologii Uniwersytetu Wrocławskiego.

Bęben, W. (1998). Mity krajowców wyspy Biem. W: P. Kowalski (red.), Wszystek krąg ziemi. Antropologia. Historia. Literatura. Prace ofiarowane Profesorowi Czesławowi Hernasowi (s. 117-130). Wrocław: Wydawnictwo Uniwersytetu Wrocławskiego.

Bęben, W. (1998). Tanep - wódz na wyspie Biem (Papua-Nowa Gwinea). W: B. Kopydłowska-Kaczorowska, F.M. Rosiński (red.), Ludy i kultury Australii i Oceanii: materiaty z VI konferencji naukowej zorganizowanej we Wroctawiu w dniach 26 i 27 listopada 1994 r. przez Katedrę Etnologii Uniwersytetu Wrocławskiego (s. 29-44). Wrocław: Katedra Etnologii Uniwersytetu Wrocławskiego.

Bęben, W. (1998). Wyspiarze z Cieśniny Torresa. W: B. Kopydłowska-Kaczorowska, F.M. Rosiński (red.), Ludy i kultury Australii i Oceanii: materiały z VI konferencji naukowej zorganizowanej we Wrocławiu w dniach 26 i 27 listopada 1994 r. przez Katedre Etnologii Uniwersytetu Wrocławskiego (s. 29-45). Wrocław: Katedra Etnologii Uniwersytetu Wrocławskiego.

Bęben, W. (2001). Tradycyjne formy życia seksualnego Melanezyjczyków. W: F.M. Rosiński (red.), Ludy i kultury Australii i Oceanii: materiaty $z$ VII konferencji naukowej zorganizowanej we Wroctawiu w dniach 26 i 27 listopada 1996 r. przez Katedrę Etnologii Uniwersytetu Wrocławskiego (s. 145-158). Wrocław: Katedra Etnologii Uniwersytetu Wrocławskiego.

Bęben, W. (2001). Wybrane elementy tradycyjnego prawa wyspiarzy Biem (Papua-Nowa Gwinea). W: F.M. Rosiński (red.), Ludy i kultury Australii i Oceanii: materiaty z VII konferencji naukowej zorganizowanej we Wroctawiu w dniach 26 i 27 listopada 1996 r. przez Katedrę Etnologii Uniwersytetu Wrocławskiego (s. 125-144). Wrocław: Katedra Etnologii Uniwersytetu Wrocławskiego. 
Bęben, W. (2002). Prawo zwyczajowe w Papui-Nowej Gwinei. W: J. Derlicki, W. Lipiński (red.), Pierwsze narody. Społeczności rdzenne i idea tubylczości we wspótczesnym świecie (s. 89-106). Warszawa: Instytut Etnologii i Antropologii Kulturowej UW/Wydawnictwo DiG.

Bęben, W. (2005). Quo vadis Papuo Nowa Gwineo. W: J. Różański (red.), Ecclesia in Oceania. Wybrane problemy kościoła w Oceanii w świetle posoborowej adhortacji Jana Pawła II (s. 219-252). Warszawa: Missio-Polonia.

Bęben, W. (2009). Spotkanie z innym człowiekiem. W: M. Horodecka (red.), Spotkanie w twórczości Ryszarda Kapuścinskiego: materiały z debat III Festiwalu Kultur Świata (s. 103-105). Gdańsk: Nadbałtyckie Centrum Kultury.

Bęben, W. (2012). Narracja o edukacji globalnej na końcu świata, czyli jak globalne przemiany dotarły pod wulkan. W: Mały człowiek w wielkim świecie. Szkolny przewodnik po globalnym świecie (s. 201-215). Gdańsk: Towarzystwo Edukacyjne „Wiedza Powszechna".

Bęben, W. (2013). Arapesze, Papua Nowa Gwinea. W: M. Łoboz, A.T. Brzyski (red.), Zawstydzona mądrość: prace ofiarowane Ojcu Profesorowi Franciszkowi Rosińskiemu OFM (s. 483-499). Wrocław: Franciszkańskie Wydawnictwo św. Antoniego.

Bęben, W. (2017). Maski Sepiku. W: M. Jarmułowicz, K. Kręglewska-Powązka (red.), Ogród sztuk. Maska (s. 75-86). Gdańsk: Wydawnictwo Uniwersytetu Gdańskiego.

Bęben, W. (2019). Religie napływowe a kultura mieszkańców Wysp Japońskich. W: J. Splisgart, A. Ozga (red.), Ziemia (nie)znana: o współczesnym odkrywaniu kultury japońskiej (s. 37-55). Gdańsk: Wydawnictwo Uniwersytetu Gdańskiego.

Bęben, W., Rosiński, F. (1996). Domy duchów w rejonie Maprik na Nowej Gwinei. W: E. Pietraszek, B. Kopydłowska-Kaczorowska (red.), Ludy i kultury Australii i Oceanii: materiaty z V konferencji naukowej zorganizowanej we Wrocławiu w dniach 26-27 listopada 1988 r. przez Katedrę Etnografii Uniwersytetu Wrocławskiego (s. 83-98). Wrocław: Katedra Etnologii Uniwersytetu Wrocławskiego.

Bęben, W., Rosiński, F. (1996). Masalaje (Masalai) we wschodnim Sepiku. W: E. Pietraszek, B. Kopydłowska-Kaczorowska (red.), Ludy i kultury Australii i Oceanii: materiały z V konferencji naukowej zorganizowanej we Wrocławiu w dniach 26-27 listopada 1988 r. przez Katedrę Etnografii Uniwersytetu Wrocławskiego (s. 71-82). Wrocław: Katedra Etnologii Uniwersytetu Wrocławskiego.

Bęben, W., Rosiński, F. (1998). Czarownice na Nowej Gwinei. W: B. Kopydłowska-Kaczorowska, F.M. Rosiński (red.), Ludy i kultury Australii i Oceanii: materiaty z VI konferencji naukowej zorganizowanej we Wrocławiu w dniach 26 i 27 listopada 1994 r. przez Katedre Etnologii Uniwersytetu Wrocławskiego (s. 96-106), Wrocław: Katedra Etnologii Uniwersytetu Wrocławskiego.

Bęben, W., Rosiński, F. (1998). Tradycyjne małżeństwo na Nowej Gwinei i jego przemiany. W: B. Kopydłowska-Kaczorowska, F.M. Rosiński (red.), Ludy i kultury Australii i Oceanii: materiały z VI konferencji naukowej zorganizowanej we Wrocławiu w dniach 26 i 27 listopada 1994 r. przez Katedrę Etnologii Uniwersytetu Wrocławskiego (s. 219-236). Wrocław: Katedra Etnologii Uniwersytetu Wrocławskiego.

Bęben, W., Rosiński, F. (1998). Uczta w społecznościach pierwotnych na Nowej Gwinei. W: P. Kowalski (red.), Oczywisty urok biesiadowania (s. 34-45). Wrocław: Towarzystwo Przyjaciół Polonistyki Wrocławskiej.

Bęben, W., Rosiński, F. (1999). Tradycyjne wierzenia i obrzędy związane ze śmiercią na Nowej Gwinei. W: Problemy współczesnej tanatologii - Medycyna - antropologia kultury humanistyka (s. 187-197). Wrocław: Wrocławskie Towarzystwo Naukowe. 
[Bęben, W. - głos w dyskusji] Gaca, M. i in. (2009). Podróżowanie do Inności. W: B. Dejna (red.), IV Festiwal Kultur Świata "Okno na Świat” - „Spotkania ze Światem” (s. 9-43). Gdańsk: Nadbałtyckie Centrum Kultury.

[Bęben, W. - głos w dyskusji] Horodecka, M. i in. (2009). Zdarzyło mi się... W: B. Dejna (red.), IV Festiwal Kultur Świata "Okno na Świat"- "Spotkania ze Światem" (s. 45-69). Gdańsk: Nadbałtyckie Centrum Kultury.

[Bęben, W. - głos w dyskusji] Przełomiec, M., i in. Konflikty świata. W: B. Dejna (red.), IV Festiwal Kultur Świata "Okno na Świat"- „Spotkania ze Światem” (s. 71-96). Gdańsk: Nadbałtyckie Centrum Kultury.

Bęben, W. i in. (2012). Co czyni przedmiot sztuką, czyli o „rzeźbie” afrykańskiej: dyskusja. W: P. Szklarzewska, K. Grabowski (red.), Afryka: fragment po fragmencie: materiaty z debat: VII Festiwal Kultur Świata "Okno na Świat”- „Spotkania ze Światem”. VI Bałtyckie Spotkanie Ilustratorów (s. 139-158). Gdańsk: Nadbałtyckie Centrum Kultury.

\section{ARTYKUŁY W CZASOPISMACH}

Bęben, W. (1987). Zwyczaje, obrzędy i wierzenia związane z uprawą yamu u ludu Arapesz w Papui Nowej Gwinei (PNG). Etnografia Polska, 31(1), 177-211.

Bęben, W. (1998). Wierzenia a moralność u ludu Arapesz w Papui-Nowej Gwinei. Quaestiones Selectae, 7, 27-35.

Bęben, W. (2003). Świat magii krajowców z wyspy Biem, Papua-Nowa Gwinea. Literatura Ludowa, 4/5, 105-119.

Bęben, W. (2004). Mały lud wokół wulkanu. Znaki Nowych Czasów, 11, 117-126.

Bęben, W. (2019). Tradycyjna kultura rdzennych ludów Australii i Oceanii: perspektywa porównawcza. Etnografia. Praktyki, Teorie, Doświadczenia, 5, 65-109.

Bęben, W., Rosiński, F. (1992). Domy duchów. Głos Świętego Franciszka, 11, 19-24.

Bęben, W., Rosiński, F. (1993). Magia miłości. Głos Świętego Franciszka, 7-8, 49-54.

Bęben, W., Rosiński, F. (1996). Sing-singi na Nowej Gwinei. Literatura Ludowa, 6, 25-41.

Bęben, W., Rosiński, F. (1996). Tradycyjne wierzenia społeczności pierwotnej Biem. Quaestiones Selectae, 3, 130-144.

Bęben, W., Rosiński, F. (1997). Stosunek społeczności pierwotnej do przyrody. Człowiek i Przyroda, 6, 109-122.

Bęben, W., Rosiński, F. (1997). Magiczne praktyki lecznicze na Nowej Gwinei. Głos Świętego Franciszka, 10, 41-45.

Bęben, W., Rosiński, F. (1997). Poetycka twórczość ludowa wyspiarzy Biem. Literatura Ludowa, 2, 31-44.

Bęben, W., Rosiński, F. (1997). Poglądy Melanezyjczyków na śmierć. Głos Świętego Franciszka, 10, 109-122.

Bęben, W., Rosiński, F. (1998). Koncepcje antropologiczne krajowców nowogwinejskich. Quaestiones Selectae, 7, s. 5-26.

Bęben, W., Rosiński, F. (1998). Osoba i rola czarownika na Nowej Gwinei. Quaestiones Selectae, 8, 43-56.

Bęben, W., Rosiński, F. (1998). Stosunek krajowców nowogwinejskich do chorób. Medycyna Nowożytna: Studium Nad Historia Medycyny, 5(2), 85-100.

Bęben, W., Rosiński, F. (1999). Twórczość prozatorska krajowców Biem. Literatura Ludowa, $3,57-71$. 
Rosiński, F.M., Bęben, W. (1991). Człowiek w społeczeństwie plemiennym (na przykładzie Arapeszów). Studia Philosophiae Christianae, 27(1), 113-132.

\section{SUMMARY}

To know, to believe, to love. Wojciech Bęben and his many worlds

The article presents the prominent Polish ethnologist and missionary, Rev. Prof. Wojciech Bęben. First, the text outlines the scholar's academic biography and describes four distinct stages of his work. The first stage was related to research in the Manam Motu Island, the second one involved long-term, in-depth fieldwork on the Bam (Biem) Island, the third included research among the peoples of New Guinea, while the last has been related to fieldwork in the Torres Strait Islands and has involved travels to Australia, New Zealand and Polynesia. In the second part, the text presents the scientific achievements of Wojciech Bęben, his publications, teaching legacy and his contribution to the organization of scientific activities.

Keywords: ethnological research, Oceania, scientific achievements, Wojciech Bęben, biography

Przeł. Agnieszka Bednarek-Bohdziewicz 